\title{
RANCANG BANGUN SMART-HOME (APLIKASI INSTALASI PERANGKAT ENERGI ALTERNATIF SINAR MATAHARI DALAM DISAIN RUMAH TINGGAL)
}

\author{
Septana*, Eddy Prianto *,J.Alfonsus Arista Tefa** \\ * Departemen Arsitektur, Fakultas Teknik, Universitas Diponegoro \\ ** PT.ATMI Kreasi Energi - Solo
}

\begin{abstract}
The development of non-polluted renewable energy such as solar power, wind power, hydro power, sea wave power, growed rapidly in accordance with the technology developments in the recent decade.

The electric energy from PLN (Indonesian Electricity Company) obtained from fuels processed through power plant converted into electrical energy. Generally, the use of electricity as a major power generator causes pollution, besides the price of fossil fuels tends to rise that make the increase in investment. One of abundantly alternative energy in Indonesia is solar radiation. The employing of of solar energy used solar panels (solar cell) convert sunlight into electrical energy directly. It easily employs in residencies commonly referred to Solar Home System.The synergistic home design which applies active design tools called Smart Home. As the development of a power plant has no synchronization with the residential design, this research purposes to observe and synchronize the installation of alternative energy device in residencies. The cooperation with PT ATMI Kreasi Energy was very advantageous for developing this subject matter from other perspectives in the future.
\end{abstract}

Keywords: Smart home, alternative energy, Sunlight, ATMI Solo

\section{Pendahuluan}

Suatu kutipan posisi peran instalasi Fotovoltaic pada suatu bangunan, khususnya pada rumah tinggal, dapat kita simak berita detail seluruh beritanya dengan judul ulasaannya "Pemerintah Bidik Pemasangan solar paner di Atap Sejuta Rumah" pada media massa "http:// detik finace.com tanggal 15September 2017 (Agustinus, 2017)

"Pada 13 September 2017 kemarin di tengahtengah acara jamuan makan malam dalam rangka Indo EBTKE Connex dan Bali Clean Energy Forum 2017, telah dilaksanakan Deklarasi Gerakan Nasional Sejuta Surya Atap

Menuju Gigawatt Fotovoltaik di Indonesia. Deklarasi ini didukung berbagai pihak, baik pemerintah maupun masyarakat melalui berbagai asosiasi masyarakat dan perusahaan.

Dalam acara itu ada Dirjen EBTKE Kementerian ESDM, Dirjen ILMATE Kementerian Perindustrian, Badan Pengkajian dan Penerapan Teknologi (BPPT), Masyarakat Energi Terbarukan Indonesia (METI), Konsorsium Kemandirian Industri Fotovoltaik Indonesia, Asosiasi Energi Surya Indonesia, Asosiasi Pabrikan Modul Surya Indonesia, Perkumpulan Pengguna Listrik Surya Atap, serta beberapa asosiasi lainnya.
Gerakan ini dilatarbelakangi oleh keinginan memperkuat ketahanan energi nasional melalui pencapaian target Energi Baru Terbarukan dalam bauran energi primer sebagaimana yang ditetapkan dalam Kebijakan Energi Nasional yang menargetkan adanya peningkatan bauran Energi Terbarukan dari 5\% pada 2015 menjadi

$23 \%$ pada 2025. Dari target Energi Terbarukan

$23 \%$ bauran energi nasional ini, proyeksi Pembangkit Listrik Tenaga Surya adalah sebesar 5.000 MWp di 2019 dan 6.400 MWp pada 2025. Hingga saat ini, pemanfataan Pembangkit Listrik Tenaga Surya secara nasional 2017 baru mencapai 80 MWp. Kendala terbesar tercapainya target bauran energi nasional ini adalah minimnya investasi IPP akibat masalah kurang menariknya investasi karena beberapa persoalan keekonomian seperti persoalan dukungan finansial termasuk bunga bank yang terlalu tinggi, tantangan dalam akuisisi lahan, maupun kendala teknis seperti terbatasnya ketersediaan jaringan interkoneksi dan lain-lain. "Potensi pemanfaataan energi surya di Indonesia sebenarnya sangat luas, dapat digunakan untuk melistriki daerah-daerah terpencil dan terisolasi yang ketersediaan sumber daya energi lainnya tidak tersedia atau karena bebannya terlalu tersebar sehingga tidak akan ekonomis bila menggunakan pembangkit listrik lainnya," kata Direktur Aneka 
Energi Baru Terbarukan Kementerian ESDM, Maritje Hutapea, dalam keterangan tertulis, Kamis (14/9/2017). Pemanfaatannya pun sangat luas, mulai dari penerangan rumah dan jalan, menjadi catu daya sistem telekomunikasi, catu daya rambu-rambu lalu lintas serta pompa air. Untuk mendorong peningkatan penetrasi teknologi listrik tenaga surya (solar photovoltaic) di Indonesia sehingga dapat tercapai 'The First Gigawatt Solar Power' sebelum 2020, dibutuhkan lompatan yang besar dalam 2 tahun, karena di 2019 diharapkan ada sekitar 5.000 MWp pemanfaatan PLTS. Diperlukan sebuah gerakan secara nasional untuk mengajak masyarakat terlibat secara aktif berpartisipasi menggunakan Pembangkit Listrik Tenaga Surya melalui berbagai skema pendanaan yang menarik dan insentif untuk makin membuka pasar tanpa perlu tergantung pada anggaran pemerintah. Saat ini di dunia, harga sel dan modul surya juga semakin murah, harga listrik dari surya sudah sangat kompetitif dibandingkan dengan harga listrik dari pembangkit listrik lainnya. Harga modul surya saat ini telah berada di bawah US\$ $1 / \mathrm{Wp}$ dan cenderung akan menurun terus hingga berada di kisaran US\$ $0,5 / \mathrm{Wp}$. Ini berakibat menjadikan harga sistem berada di sekitar US\$ 1.500 / kWp dan biaya pokok produksi Pembangkit Listrik Tenaga Surya berada di kisaran US\$ 0,04/ kWh. "Menurunnya harga modul surya ini sebagai akibat dari unjuk kerja dari modul yang lebih baik dalam beberapa tahun terakhir karena meningkatnya efisiensi modul serta akibat dari tercapainya skala keekonomian karena produksi modul surya yang sangat masif. Pemanfaatan Pembangkit Listrik Tenaga Surya di beberapa negara telah mencapai skala Gigawatt. Tren pasar dunia penggunaan Pembangkit Listrik Tenaga Surya meningkat dari 6,5 GWp pada 2008 menjadi $81 \mathrm{GWp}$ pada 2016 yang mengakibatkan harga penjualan yang semakin turun signifikan," ujar Maritje.Pembangkit Listrik Tenaga Surya juga dimanfaatkan untuk mendorong pengurangan emisi $\mathrm{CO} 2$ di udara karena lebih ramah lingkungan. Dasar pemikiran diusulkannya

Gerakan ini adalah karena di Pulau Jawa ada 30 juta pelanggan rumah tangga dimana sepertiganya merupakan rumah menengah ke atas, atau 10 juta rumah.

"Kalau 10 juta rumah memasang Pembangkit Listrik Tenaga Surya di masing-masing atapnya4 KW saja, ini sudah mencapai 4,000 MWp. Kalau hanya seperempatnya saja, ini pun masih mencapai 1 Gigawatt. 1 Gigawatt di Pulau Jawa tidak akan berpengaruh besar terhadap sistem kelistrikan, karena penggunaan listrik di siang hari sudah di atas 10.000 MW. Jika diberi kebijakan dan rangsangan yang tepat, maka Pembangkit Listrik Tenaga Surya atap bisa menjadi pilar dalam mencapai 5.000 MWp. Ini akan menjadi potensi yang sangat besar. Dengan Potensi pasar tinggi ini, maka pengembangan industri PV di Indonesia akan menjadi sebuah keniscayaan," tutup Maritje. (mca/mca) (Agustinus, 2017)

Sejauh mana aplikasi terapan perangkat sederhana dari system fotovoltaic produk PT.ATMI Solo dapat terintegrasi dalam disain arsitektur dan seberapa jauh saat ini peluang pemakaiannya dibanding dengan energy listrik dari PLN. Kedua hal tersebut diatas menjadikan pertanyaan dalam penelitian kami ini.

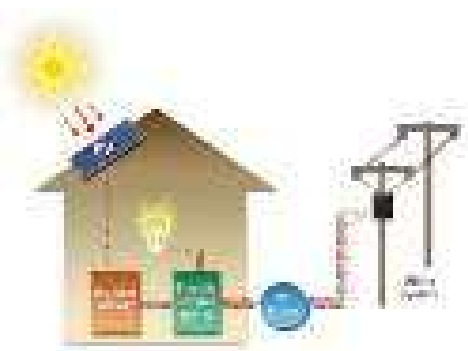

Gambar 1: Ilustrasi Energy-Home (realitypod.com, -)

\section{Definisi Fotovoltaik}

Fotovoltaik (PV) adalah sektor teknologi dan penelitian yang berhubungan dengan aplikasi panel surya untuk energi dengan mengubah sinar matahari menjadi listrik. Karena permintaan yang terus meningkat terhadap sumber energi bersih, pembuatan panel surya dan kumpulan fotovoltaik telah meluas secara dramatis dalam beberapa tahun belakangan ini. (Wikipedia, 2017).

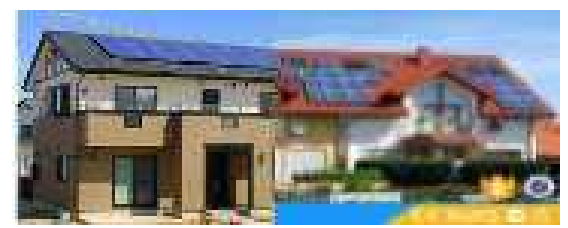

Gambar 2: Beberapa aplikasi instalasi Photovoltaic pada atap rumah (Prasetyo 2011)

Produksi fotovoltaik telah berlipat setiap dua tahun, meningkat rata-rata 48 persen tiap tahun sejak

2002, menjadikannya teknologi energi dengan pertumbuhan tercepat di dunia. Pada akhir 2007, menurut data awal, produksi global mencapai 12.400 megawatt. Secara kasar, 90\% dari kapasitas generator ini meliputi sistem listrik terikat. Pemasangan seperti ini dilakukan di atas tanah (dan kadang-kadang digabungkan dengan pertanian dan penggarapan) atau dibangun di atap atau dinding bangunan, dikenal sebagai Building Integrated Photovoltaic atau BIPV 


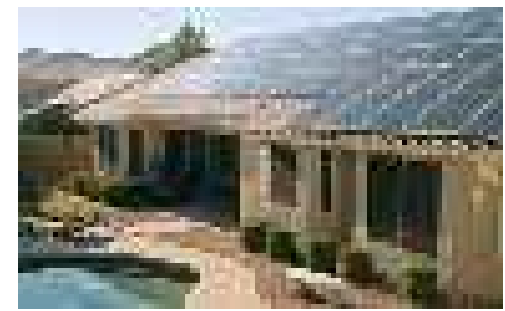

Gambar 3 : Prinsip kerja Photovoltaic (realitypod.com, -)

\section{Mengenal Solar Home System}

Cahaya matahari merupakan salah satu bentuk energi dari sumber daya alam. Sumber daya alam matahari sudah banyak digunakan untuk memasok daya listrik di satelit komunikasi panel surya. Sel surya ini dapat menghasilkan energi listrik dalam yang tidak terbatas langsung diambil dari matahari, tanpa ada bagian yang berputar dan tidak memerlukan bahan bakar. Sehingga sistem sel surya sering dikatakan bersih dan ramah lingkungan. Dibandingkan genarator listrik ada yang berputar dan memerlukan bahan bakar untuk dapat menghasilkan listrik, suaranya bising. Salain itu gas buang yang dihasilkan dapat menimbulkan efek gas rumah kaca (green house gas) yang pengaruhnya dapat merusak ekosistem mahluk hidup di muka bumi.

Solar home system adalah merupakan suatau pembangkit listrik tenaga surya berskala kecil terdiri dari komponen panel surya, batrai charger controller, batrai, dan inverter. Beban yang dipasang pada pembangkit berskala kecil ini dapat berupa lampu florescent, radio, televise berwarna yang dioprasikan dalam 4 atau 5 jam setiap hari.

Panel surya yang banyak digunakan untuk solar home system dalam skala kecil ini biasanya bervariaso dari 50-200 watt. Baterai dibutuhkan dalam pembangkit ini dengan tujuan pada saat malam hari ataupun selama cuaca hujan sehingga tidak terdapat sinar matahari listrik masih dapat dimanfaatkan.

Pada dasarnya Solar Home System adalah bentuk applikasi dari tenaga surya, pembangkit listrik tenaga surya itu konsepnya sederhana. Saat energi foton yang diserap oleh lapisan negatif dari solar sel telah cukup, maka elektron akan dibebaskan dari lapisan negatif menuju ke lapisan positif, sehingga timbul beda potensial alias tegangan. Dari situlah akan timbul energi listrik yang nantinya dapat disimpan ke dalam sebuah baterai.

\section{Sekilas PT ATMI Solo (ATMI-solo, 2017)}

Politeknik ATMI, sebelumnya bernama: Akademi Tehnik Mesin Industri (ATMI) Surakarta adalah akademi teknik mesin yang berdiri sejak tahun 1968 di bawah naungan Yayasan Karya Bakti Surakarta berkembang menjadi institusi pendidikan tinggi yang mempunyai pengaruh cukup besar pada pendidikan profesional khususnya di bidang Teknik Mesin Industri (Teknik Manufaktur). Sejak kunjungan Menteri Pendidikan Republik Indonesia Prof. Dr. Ing. Wardiman Djojonegoro pada tahun 1995, ATMI Kota Surakarta makin dilibatkan dalam pengembangan pendidikan kejuruan di Indonesia.

Politeknik ATMI Surakarta adalah institusi pendidikan tinggi yang berkonsentrasi pada pendidikan vokasi di bidang manufaktur (mesin industri) di Indonesia yang mengadopsi model pendidikan dual system dari Jerman dan Swiss.

Politeknik ATMI Surakarta berdiri pertama kali pada tahun 1968 dengan nama ATMI (Akademi Tehnik Mesin Industri) dan sejak berdiri telah menggunakan sistem pendidikan yang berbasis produksi atau PBET (Production Based Education and Training). Lulusan Politeknik ATMI Surakarta selalu disesuaikan dengan kebutuhan dunia industri karena pendidikan di Politeknik ATMI Surakarta membekali mahasiswa menjadi ahli madya yang trampil dan berkarakter. Politeknik ATMI adalah institusi pendidikan setingkat universitas di Indonesia yang pertama kali mendapat sertifikat penjaminan mutu ISO dalam bidang edukasi dan produksi. Penjaminan mutu ISO 9001:2000 ini didapatkan sejak 21 September 2001 dan penerapannya selalu diaudit setiap tahun. Pembaharuan standard ke ISO 9001:2008 telah dilaksanakan pada tanggal 18 Mei2010 dengan nomor sertifikat 01100075858 dan 01100075859.

Politeknik ATMI yang kampusnya terletak di Jl Laksda Adi Sucipto Gg Mojo 1, Karangasem, Laweyan, Solo 57145 Jawa Tengah[1] ini memiliki 3 program studi, yakni: Teknik Mesin Industri, Teknik Mekatronika, serta Teknik Perancangan Mekanik dan Mesin. Selain berfokus pada pendidikan dan produksi, Politeknik ATMI juga aktif dalam pelatihan/training, menjadi konsultan politeknik dan program-program lain seperti I-Cell (Business Incubator), Bizdec (consultancy), Solo Techno Park (teaching factory, training center), dan lain-lain.

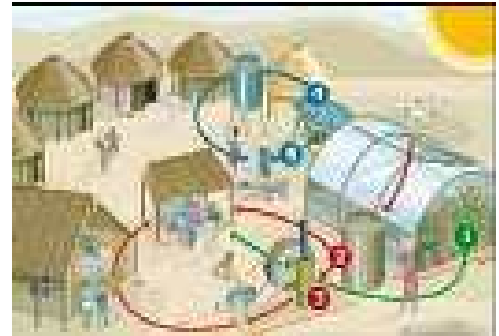

Gambar 4 : Sketsa visualisasi kampong ramah lingkungan kreasi PT.Atmi Solo (kiri) dan Sonnenschiff sebuah kota di Freiburg Jerman (Prasetyo 2011) 
Mengenal perangkat sumber energy alternative : SHS (ATMI-Solo, 2017)

Produk Ecohome dan Sunvention SunPulse water, menjadi produk andalan dari ATMI solo dari tahun 2013. ATMI memiliki keprihatinan besar terhadap masalah energi terbarukan. Konsep "green" dalam kebijakan ATMI secara nyata tampak dalam pemeliharaan pepohonan di kompleks ATMI, dan pemilihan penggunaan dan penciptaan teknologi yang ramah lingkungan. Para expert di ATMI bekerja sama dengan institusi lain mengembangkan berbagai aplikasi teknologi terbarukan. ATMI bersama HOLCIM membangun rumah berkonsep ramah lingkungan, di mana bangunan dibuat denganarsitektur yang ramah lingkungan dan menggunakan teknologi yang juga ramah.

ATMI bekerja sama dengan Sunvention dari Jerman, mengembangkan pembuatan pompa air dengan energi matahari. ATMI telah mengirimkan instruktur ke Lörrach, Jerman untuk belajar teknologi pembuatan pompa air ini. Ke depan ATMI akan memproduksi pompa air ini untuk membantu para petani di daerah yang tidak mempunyai akses listrik agar dapat tetap mengairi sawah mereka

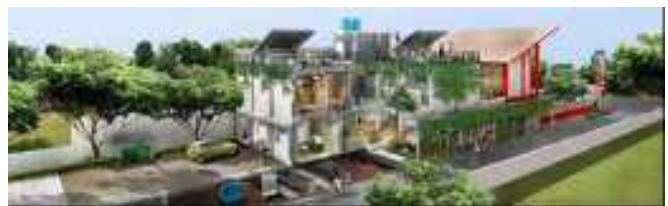

Gambar 5 : Sketsa visualisasi Rumah Ramah Lingkungan (ATMI-Solo 2017)

Solux, yang dibuat oleh PT ATMI Kreasi Energi ini besar dari lensa Fresnel adalah $30 \times 30 \mathrm{~cm}$ yang mampu menerangi satu ruangan sebesar $4 \times 4 \mathrm{~m}$, dengan harga perunitnya $\mathrm{Rp} 15.000 .000,-$ dan mampu bertahan hingga 3-5 tahun. Solux adalah perangkat yang menangkap sinar atau cahaya matahari dan kemudian mengkonsentrasikannya pada lensa Fresnel dan lensa infrared yang kemudian dialirakn pada sebuah pipa fiber optik dengan tujuan membawa sinar tersebut masuk kedalam ruangan tertutup tanpa jendela. Solux selalu menikuti gerak dari matahari sehingga permukaan lensa Fresnel selalu tegak lurus dengan sinar matahari. Sebuah sensor dengan control elektronik yang dilengkapi dengan dua buah motor elektrik merupakan unit control dan penggerak yang selalu bekerja untuk menentukan posisi lensa Fresnel.

Sinar matahari mengenai lensa Fresnel dan dikonsentrasikan pada titik focus. Pada titik tersebut cahaya mulai diarahkan untuk masuk kedalam melalui pipa optic. Pipa optic terbuat dari pipa fleksibel dengan cairan khusus yang mentransmisikan cahaya dengan efisiensi yang tinggi ke sebuah pembias cahaya yang akan menerangi ruangan. Diantara lensa fresnel dan pipa optic terdapat penyaring infrared yang diataur secara diagonal yanag akan merefleksikan panas dari sinar matahari pada titik focus kedua. Hal ini dibaut untuk menghindari pipa optic dari panas. Pada titik focus kedua kita dapat memanaskan sesuatu seperti untuk membakar kayu atau menambahkan perantara panas untuk membuat air panas. Solux selalu menikuti gerak dari matahari sehingga permukaan lensa Fresnel selalu tegak lurus dengan sinar matahari. Sebuah sensor dengan control elektronik yang dilengkapi dengan dua buah motor elektrik merupakan unit control dan penggerak yang selalu bekerja untuk menentukan posisi lensa Fresnel. Sinar matahari mengenai lensa Fresnel dan dikonsentrasikan pada titik focus. Pada titik tersebut cahaya mulai diarahkan untuk masuk kedalam melalui pipa optic. Pipa optic terbuat dari pipa fleksibel dengan cairan khusus yang mentransmisikan cahaya dengan efisiensi yang tinggi ke sebuah pembias cahaya yang akan menerangi ruangan. Diantara lensa fresnel dan pipa optic terdapat penyaring infrared yang diataur secara diagonal yanag akan merefleksikan panas dari sinar matahari pada titik focus kedua. Hal ini dibaut untuk menghindari pipa optic dari panas. Pada titik focus kedua kita dapat memanaskan sesuatu seperti untuk membakar kayu atau menambahkan perantara panas untuk membuat air panas.

\section{Metoda Penelitian}

Metode yang digunakan dalam penelitian ini adalah deskriptif analisis dengan melakukan pengumpulan data secara in-situ, yaitu di laboratorium PT ATMI Kreasi Energi-Solo. Dimana tempat ini merupakan salah satu mitra kerja pengembangan teknologi rancang bangun. Dan langkah berikutnya adalah kajian arsitekturis guna mendapatkan tingkat effesiensi penggunaan dan penerapan alat ini pada skala rumah tinggal. Kemudian dilakukan pra rencana dan alternative terapannya.

\section{Lokasi Obyek, Alat dan Bahan}

Beberapa alat survey dan alat ukur yang digunakan adalah kini sudah serba digital, seperti alat ukur, pengukuran penerangan, camera hingga kompas (lihat gambar dibawah).

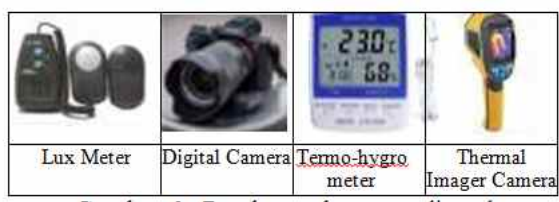

Gambar 6 : Peralatan ukur yang digunakan 


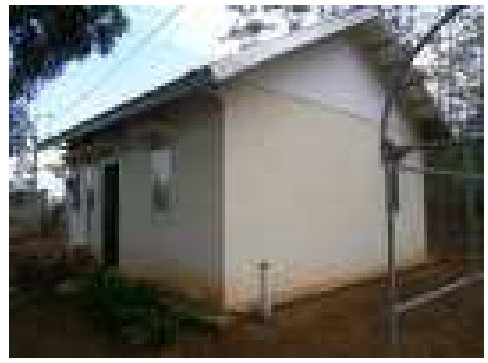

Gambar 7 : rumah obyek pengamatan (bawah)

Peta lokasi obyek pengamatan adalah di lingkungan PT.ATMI Kreasi Energi-Solo (lihat foto satelit google map) pada gambar 6 .

\section{hasil dan pembahasan}

Dalam pembahasan ini, akan dibagi menjadi beberapa tahapan, yaitu :

- Rancang bangun atap I-Roof produk ATMI Solo

- Rancang bangun SOLUX produk ATMI Solo

- Rancang bangun Smart-Home-System (SHS) produk ATMI SAolo

- Konsep Rancang Bangun SMART-HOME untuk bangunan Rancang bangun atap I-Roof (ATMI-Solo 2017)

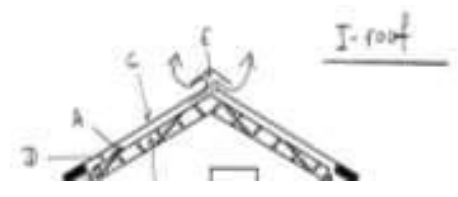

Gambar 8 : a). Konsep instalasi I-Roof dan rumah model

Menurut paparan pihak ATMI, Ide awal konstruksi atap I-Roof adalah fungsi lain dari penggunaan atap baja profil miring normal dan diletakannya diatas suatu bidang atap ruamh, yang awalnya digunakan sebagai pengering untuk rumput laut, tanaman atau buah-buahan. Dalam pelaksanaan beberapa waktu, di ambil kesimpulan bahwa proses pengeringan ini murah dan mudah. Berangkat dari

„percobaan tersebut ${ }^{\text {e }}$ tersebut, oleh pihak tim ATMI : Mengapa tidak dibautkan sebuah sistem pendingin udara untuk ruangan dibawahnya? Secara prinsip dapat diartikan juga sebagai penangkap sinar matahari yang dikonversi menjadi system pengontrol ruangan. (ATMI-Solo 2017)

Bahan dan fungsi instalasi atap I-Roof dapat

dilihat pada gambar 7, dimana system ini tersusun dari bahan-bahan sebagai berikut :

- Glass Wool : Bahan tergolong mudah didapat, dapat menahan dan mengisolasi panas, harga terjangkau, mudah dibentuk.
- Alumunium Foil : Pemantul panas yang baik, tahan lama \pm 4 tahun, mudah didapat dan harga terjangkau.

- Plastik Novovol : penahan panas dan hujan, mampu meneruskan sinar matahari.

- Plat cat hitam : plat yang dicat warna hitam akan dengan maksimal menangkap sinar/panas matahari.

\section{a. Proses Kerja I-Roof}

Atap seng digunakan sebagai atap dari rumah tinggal tersebut, lalu plat dengan cat warna hitam yang berperan sebagai penangkap sinar atau panas matahari yang nantinya akan diteruskan ke plastik novovol yang berada di bawah plat tersebut. Ketika suhu di atas (atap) mulai memanas, suhu tersebut akan di simpan di sebuah ruangan dan alumunium foil akan mengikatnya, agar tidak turun ke dalam ruangan. Alumunium foil sendiri dapat mengikat panas hingga 97\% dari suhu yang diikat. Glass wool yang berperan sebagai pereduksi suara, juga mampu untuk mengikat panas membantu alumunium foil.

b. Gagasan merancang aplikasi Disain I- Roof pada bangunan Rumah Tinggal

Aplikasi instalasi I-roof dapat dilakukan pada semua bidang atap yang memilki kemiringan diatas 30 derajad. Tidak harus disemua sisi bidang atap, $d$ tapi pilihan yang tepat terhadap ororientasi arah datang sinar matahari. Untuk daerah tropis seperti Negara kita, permukaan bidang atap relative sama peran dan manfaatnya dalam mendapatkan pancaran sinar matahari.

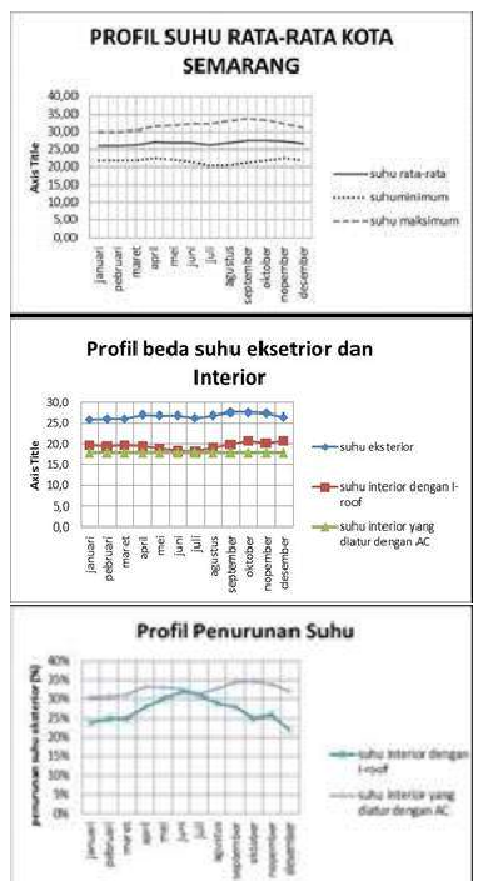

Gambar 10 : Profil suhu rata-rata kota Semarang dalam setahun. 
c. Kajian kritis rancang bangun disain I-Roof

Cara kerja alat ini ternyata dalam prakteknya memiliki kelemahan pada tingkat pengontrolan suhu ruangan dalam .

- Suhu interior yang terjadi dari pemakaian atap I-roof, mengalami rata-rata reduksinya berkisar antara \pm $22 \%-30 \%$.

- Sedangkan suhu interior yang terjadi dari pemakaian AC (dianggap terkontrol secara maksimum), dapat dihitung rata-rata berkisar diatas $30 \%$ atau antara $\pm 31 \%-35 \%$.

Dari kendala pemakaian I-roof, suhu interiornya tidaklah bisa dipredisi ataupun dikontrol oleh pengguna, tidak halnya dengan pemakaian Air Conditioning, dimana suhu interiornya dapat diatur. Secara singkat, bahwa pengembangan alat I-roof ini bilamana memungkinkan dilengkapi alat pengontrol (?). Bilamana dihitung konsumsi energy yang harus dikeluarkan, maka tentus aja pemakaian I-roof akan bebas biaya pembayaran langganan listrik.

Gambar 9 adalah pensimulasian penurunan suhu ruangan terhadap suhu eksterior, dengan kondisi penurunan rata-rata seperti tersebut diatas, untuk suatu data simulasi iklim dikota Semarang. Dimana dapat disimak bahwa penurunan suhu interior mencapai tingkatan maksimum pada bulan april- agustus.

\section{Rancang bangun SOLUX (ATMI-Solo 2017)}

Solux adalah perangkat yang menangkap sinar atau cahaya matahari pada siang hari dan kemudian mengkonsentrasikannya pada lensa Fresnel dan lensa infrared yang kemudian dialirkan pada sebuah pipa fiber optik dengan tujuan membawa sinar tersebut masuk kedalam ruangan tertutup tanpa jendela.

a. Proses Kerja Alat Solux

Solux selalu menikuti gerak dari matahari sehingga permukaan lensa Fresnel selalu tegak lurus dengan sinar matahari. Sebuah sensor dengan control elektronik yang dilengkapi dengan dua buah motor elektrik merupakan unit control dan penggerak yang selalu bekerja untuk menentukan posisi lensa Fresnel. Sinar matahari mengenai lensa Fresnel dan dikonsentrasikan pada titik focus. Pada titik tersebut cahaya mulai diarahkan untuk masuk kedalam melalui pipa optic. Pipa optic terbuat dari pipa fleksibel dengan cairan khusus yang mentransmisikan cahaya dengan efisiensi yang tinggi ke sebuah pembias cahaya yang akan menerangi ruangan. Diantara lensa fresnel dan pipa optic terdapat penyaring infrared yang diataur secara diagonal yanag akan merefleksikan panas dari sinar matahari pada titik focus kedua. Hal ini dibaut untuk menghindari pipa optic dari panas. Pada titik focus kedua kita dapat memanaskan sesuatu seperti untuk membakar kayu atau menambahkan perantara panas untuk membuat air panas.

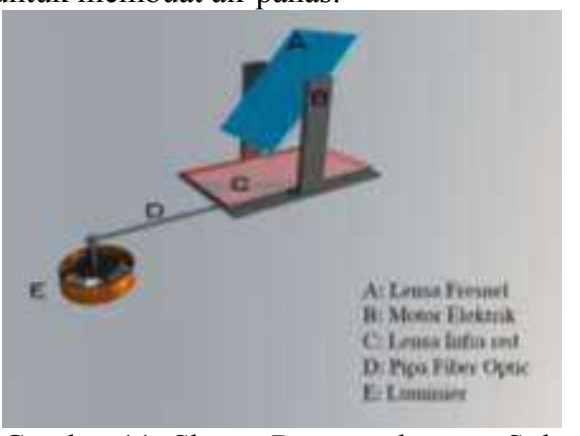

Gambar 11: Skema Rancang bangun Solux

b. Gagasan merancang aplikasi Disain SOLUX pada bangunan Rumah Tinggal

Pemasangan SOLUX yang dirancang dimana lensa fresnel dan pipa optic yang ditempatkan pula penyaring infrared dapat diatur secara diagonal yang akan merefleksikan panas dari sinar matahari pada titik focus kedua. Dengan demikian dibuat untuk menghindari pipa optic dari panas. Pada titik focus kedua kita dapat memanaskan sesuatu seperti untuk membakar kayu atau menambahkan perantara panas untuk membuat air.

Fungsi yang demikian lebih tepat di tempatkan diarea Garasi ataupun dapur, atau bahkan lebih tepat untuk perumahan di daerah pegunungan. Panas yang dihasilkan dapat difungsikan untuk membakar kayu atau memanaskan air.. Dalam perkembangannya perlu dilengkapi semacam bateray untuk menyimpan $\mathrm{p}$ [anas tersebut dan digunakan pada malam hari.

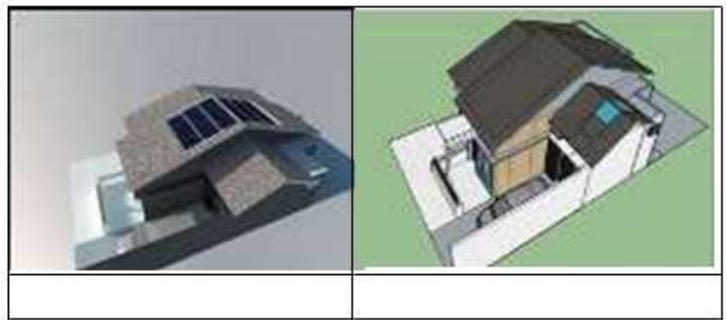

Gambar 12: Skema Aplikaasi pada rumah tinggal: diletakkan pada atap garasi/bangunan annex (a), diletakkan pada atap garasi/bangunan annex (b)

Fungsi kedua, proses menjadikan sinar atau panas matahari yang didapat dari lensa Fresnel akan dipantulkan ke lensa infrared yang bertujuan menyaring panas dan cahaya yang disalurkan dari lensa Fresnel, peletakan lensa infrared berada di dalam atap tepatnya $d$ iatas kuda-kuda yang nantinya akan disalurakan lagi menggukananpipa fiber optik, cahaya mulai diarahkan untuk masuk kedalam melalui pipa optic. Pipa optic terbuat dari pipa fleksibel 
dengan cairan khusus yang mentransmisikan cahaya dengan efisiensi yang tinggi ke sebuah pembias cahaya yang akan menerangi ruangan yang tertutup tanpa adanya jendela. Maka dalam aplikasi pemasangan pada rumah tinggal dapat dipasang diatas ruangan yang sama sekali tidak mendapatkan pencahaan pada siang hari (Prianto, 2017).

c. Kajian kritis rancang bangun disain SOLUX Perangkat ini tidak dapat dirubah atau didesain ulang, karena sudah dipatenkan oleh pihak ATMI, dengan berupa bentuk produk yang sudah jadi, tetapi pengembangan desain dapat dilakukan asalkan proses dan hasil yang terjadi masih sama seperti desain awal dari PT ATMI Kreasi Energi. Untuk solux yang telah dibuat oleh PT ATMI Kreasi Energi ini besar dari lensa Fresnel adalah $30 \times 30 \mathrm{~cm}$ yang mampu menerangi satu ruangan sebesar $3 \times 4 \mathrm{~m}$, dengan harga perunitnya $\mathrm{Rp}$ 15.000.000,- dan mampu bertahan hingga 3-5 tahun.

Tabel 1 Tabel perbandingan harga dan konsumsi energy antara pemasangan lampu dan Solux.

\begin{tabular}{|c|c|c|c|c|c|c|c|}
\hline \multirow{2}{*}{ merever } & & \multirow[b]{2}{*}{ ant. } & 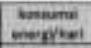 & interine. & per ins & \multirow{2}{*}{ 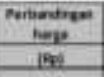 } & \multirow[t]{2}{*}{ noveris } \\
\hline & & & & Namil & & & \\
\hline 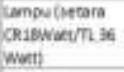 & Ap. & 75000 & If & 15950 t & $7 \pi N 00$ & 1555200 & Lex \\
\hline sowix & $3 p$ & 1500ane & & & & 15000000 & $x=2$ \\
\hline 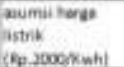 & An & 2000 & 364 & Inow & $1555 \% 00$ & & \\
\hline
\end{tabular}

Mencermati perbandingan harga dari optimalisasi antara pemakaian Lampu CR 18Watt (setara TL36 watt) untuk masa pakai 5 tahun dan pembelian SOLUX seharga Rp.15.000.000 (lima • Alat-alat tersebut, merubah ,dampak ${ }^{\text {ee }}$ positif dari factor iklim (sinar dan panas matahari) belas juta rupiah). Dapat kami simpulkan bahwa menjadi energy panas dan cahaya/penerangan (lihat tabel diatas). Pemakaian lampu sejauh ini masih serta listrik. Dimana output dari alat-alatsangat murah dibanding dengan pemasangan instalasi tersebut dapat untuk digunakan : pengeringan,SOLUX (Rp. 1.500 .000 dibanding Rp.15.000.000). pemanasan, pendinginan, energy listrik

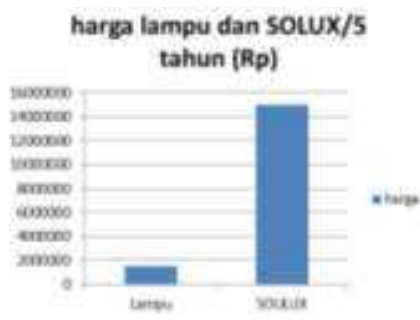

Gambar 13: penerangan maupun menghidupkan alat elektronik ( BSNI, 2011)

,alate, menyesuaikan tempat atau membangun tempat (disain berubah) pada aspek kreatifitas disain
ATAP. Bisa dalam bentuk menempel, membentuk atap, terpisah (double skin) atap, bahkan bentuk atap yang kreatif (Prianto, 2017), (Prianto, 2010)

- $\quad$ Pemasangan ,alate, menyesuaikan tempat atau membangun tempat (disain berubah) pada aspek kreatifitas disain TRITISAN. Bisa dalam bentuk menempel, membentuk model tritisan tertentu, unsur dekoratif façade, lapisan dinding (double skin), bahkan bentuk tritisan yang kreatif. (Prianto, 2013)

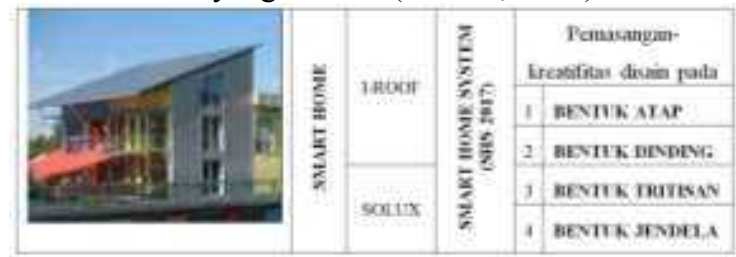

Gambar 14: Skematik aplikasi konsep rancang banguan Smart-Home

\section{kesimpulan}

Rancang Bangun Smart-Home ini, merupakan kolaborasi antara produk rancangan disain arsitek bangunan dengan produsen ala smart, yang merupakan produk dari ATMI Solo, yaitu I-Roof dan SOLUX. pemanfaatan factor iklim yang handal".

\section{Ucapan Terimakasih}

Makalah ini merupakan hasil skim Penelitian Dasar yang dikoordinir Departement Arsitektur Fakultas Teknik (DAFT) dengan dana DIPA Fakultas Teknik Universitas Diponegoro tahun 2017, dengan judul RANCANG BANGUN SMART-HOME (APLIKASI INSTALASI PERANGKAT ENERGI ALTERNATIF SINAR MATAHARI DALAM DISAIN RUMAH TINGGAL). Kegiatan ini telah tertuang dalam SK Dekan FT Undip No.170/SK/UN7.3.3/V/2017 tertanggal 15 mei 2017. Untuk itu kami ucapkan terimakasih pada semua, terutama pada bapak J.Alfonsus Arista Tefa Direktur PT.ATMI Kreasi Energi Solo yang telah membantu dan memfasilitasi semuanya sehingga terselesaikan penelitian ini.

\section{daftar pustaka}

Agustinus, M. (2017, September 15). Pemerintah bidik pemasangan Solar Panel diatas sejuta rumah. Dipetik Nopember 08, 2017, dari detik finance: http://finacedetik.com>energhi.pemerintah...

Alain, Liebard, and Andre de Herd. BIOCLIMATIC FACADES. London: Somfy, 2010.

ATMI-Solo. Projects- Sustainable Energy. - -, 2017. http://www.atmi.ac.id/index.php/projects96/sustainable-energy (accessed Oktober 4,2017). 